\title{
Host Range and Characterization of Sunflower mosaic virus
}

\author{
T. J. Gulya, P. J. Shiel, T. Freeman, R. L. Jordan, T. Isakeit, and P. H. Berger
}

First author: U.S. Department of Agriculture-Agricultural Research Service (USDA-ARS), Northern Crop Science Laboratory, Fargo, ND 58105; second and sixth authors: Department of Plant, Soil and Entomological Sciences, University of Idaho, Moscow 83844; third author: Department of Plant Pathology, North Dakota State University, Fargo 58105; fourth author: USDA-ARS, United States National Arboretum, Floral and Nursery Plants Research Unit, Beltsville, MD 20705; and fifth author: Texas A\&M University, Department of Plant Pathology and Microbiology, College Station 77843.

Accepted for publication 18 March 2002.

\begin{abstract}
Gulya, T. J., Shiel, P. J., Freeman, T., Jordan, R. L., Isakeit, T., and Berger, P. H. 2002. Host range and characterization of Sunflower mosaic virus. Phytopathology 92:694-702.

Sunflower mosaic is caused by a putative member of the family Potyviridae. Sunflower mosaic virus (SuMV) was characterized in terms of host range, physical and biological characteristics, and partial nucleotide and amino acid sequence. Cells infected with SuMV had cytoplasmic inclusion bodies typical of potyviruses. Of 74 genera tested, only species in Helianthus, Sanvitalia, and Zinnia, all Asteraceae, were systemic hosts. Commercial sunflower hybrids from the United States, Europe, and South Africa were all equally susceptible. The mean length of purified particles is approximately $723 \mathrm{~nm}$. The virus was transmitted by

Myzus persicae and Capitphorus elaegni, and also was seedborne in at least one sunflower cultivar. Indirect enzyme-linked immunosorbent assay tests with a broad-spectrum potyvirus monoclonal antibody were strongly positive. SuMV-specific polyclonal antisera recognized SuMV and, to a lesser extent, Tobacco etch virus (TEV). When tested against a panel of 31 potyvirus-differentiating monoclonal antibodies, SuMV was distinct from any potyvirus previously tested. SuMV shared four epitopes with TEV, but had a reaction profile more similar to Tulip breaking virus (TBV). SuMV did not possess epitopes unique only to TBV. The predicted coat protein had a molecular weight of $30.5 \mathrm{kDa}$. The $3^{\prime}$ end of the virus genome was cloned and sequenced. Phylogenetic analysis of the coat protein amino acid sequence revealed that SuMV is a distinct species within the family Potyviridae, most closely related to TEV.
\end{abstract}

Virus diseases of cultivated sunflower (Helianthus annuus L.) or other wild species of the genus Helianthus are rare. In the United States, there are only records of sunflower naturally infected by Cucumber mosaic virus (CMV) in research plots in Beltsville, MD (20), Tobacco ringspot virus infecting wild sunflower in the Rio Grande Valley of Texas (16), and Sunflower mosaic virus (SuMV) infecting wild $H$. annuus near Austin, TX (2). Viruses have either never been observed or confirmed on cultivated sunflower in the major production areas of the United States, which are the northern Great Plains (North Dakota, South Dakota, and Minnesota) and the High Plains (Kansas, Colorado, and Nebraska), or seed production areas of California (22). In other countries, natural occurrences of viruses infecting cultivated sunflower have been reported, including CMV in Japan (19) and India (25), an unknown virus causing yellow blotch and leaf crinkle in Kenya (24), Tobacco streak virus in the Netherlands (7), Sunflower chlorotic mottle virus in Argentina (8), Potato virus $Y$ in Czechoslovakia (6), an unidentified virus causing mosaic in India (18), and Tomato spotted wilt virus in the Ukraine (26). In addition to these records, the VIDE online database lists 36 viruses shown to experimentally infect and induce symptoms in sunflower (5). Of the viruses reported to infect sunflower naturally or experimentally, nine are in the family Potyviridae: Artichoke latent virus (ArLV), Bidens mosaic virus (BiMV), Bidens mottle virus (BiMoV), Clover yellow vein virus (ClYVV), Patchouli mosaic virus, Pepper veinal mottle virus (PVMV), Sunflower chlorotic mottle virus (SuCMoV), SuMV, and Tropaeolum virus 2 (TV-2). The reactions of a range of diagnostic hosts to these potyviruses are listed in Table 1.

Corresponding author: P. H. Berger; E-mail address: pberger@uidaho.edu

Publication no. P-2002-0506-01R

(C) 2002 The American Phytopathological Society
SuMV originally was reported on wild $H$. annuus in Austin, TX in 1966, and an ultrastructural study indicated that the causal agent was a potyvirus based on particle morphology and cytopathology (2). Sunflower in Texas is grown either for planting seed intended for the northern Great Plains area or as confection sunflower for U.S. and foreign consumption. No viruses have been recorded on cultivated or wild sunflower in the northern Great Plains; therefore, it is important to further characterize SuMV. Additionally, SuMV is classified as a pathogen of quarantine significance by many countries importing sunflower from the United States. In 1997, wild sunflowers with mosaic symptoms were observed in an abandoned sorghum field in extreme southern Texas. In subsequent years, mosaic symptoms were observed on wild sunflower in other fields in the southern Rio Grande Valley. The objective of the present study was to characterize the virus causing mosaic symptoms on sunflower in southern Texas, including a host range study, transmission studies, virus purification, and phylogenetic analysis. Portions of this work have been reported previously (9).

\section{MATERIALS AND METHODS}

Source and maintenance of the virus. Leaves of wild $H$. annuus L. showing mosaic symptoms were collected from roadside ditches and fields near Brownsville (Cameron County), McAllen, Progreso, Weslaco, and Alamo (Hidalgo County), all of which are in southern Texas in the Rio Grande Valley. Infected leaves were macerated in $0.01 \mathrm{M}$ phosphate buffer, $\mathrm{pH} 7.0$, and rubbed onto sunflower plants dusted with 600-mesh Carborundum. Several sunflower cultivars initially were used for virus maintenance, including oilseed hybrid Triumph 546, confection hybrid Sigco 954, and U.S. Department of Agriculture (USDA) inbreds RHA 271, RHA 858, and RHA 358. Plants were inoculated 14 to 18 days after planting (2- to 4-leaf stage), and symp- 
toms appeared in 8 to 12 days. In order to keep plants at a manageable height, sunflowers were routinely sprayed with the growth regulator B-Nine (daminozide, Uniroyal Chemical) at $0.5 \%$ until run-off, once per week.

Optimizing infection parameters. Several factors were studied to determine the optimum conditions for infection, including plant age at inoculation, age of leaves used for inoculum, and the use of antioxidants in the inoculation buffer. The influence of plant age on virus susceptibility was tested by inoculating RHA-271 plants at 11, 14, 17, 21, 24, 28, and 32 days after seeding. A total of 40 plants of each age were inoculated in each of three independent experiments. We also investigated the effects of a growth regulator and antioxidants on virus symptom expression in a single experiment. The growth regulator B-Nine ( $0.5 \%$ aqueous solution) was sprayed onto seedlings 3 days prior to inoculation. In the same test, the effect of the antioxidants sodium sulfite (Sigma-Aldrich, St. Louis) (1\%, wt/vol) and polyvinylpyrrolidone-40,000 (PVP, Sigma-Aldrich) $(0.25 \%$, $\mathrm{wt} / \mathrm{vol}$ ) added to the phosphate buffer in virus inoculations was studied.

Microscopy. For leaf dip preparations, several methods were employed. A freshly cut fully expanded sunflower leaf showing mosaic symptoms 2 weeks postinoculation was dipped into a drop of phosphate buffered saline (PBS) on a formvar-coated copper grid. The PBS was wicked off and the sample was stained with $1 \%$ phosphotungstic acid (PTA). Other methods consisted of dipping cut leaves into ammonium acetate and then staining with PTA, or dipping the pieces directly into PTA.

For transmission electron microscopy (TEM), 1-mm² leaf segments were dissected and fixed in $2.5 \%$ glutaraldehyde in Millonig's (17) phosphate buffer ( $\mathrm{pH} 7.3$ ) for $2 \mathrm{~h}$. The samples were washed in buffer and postfixed in $2 \%$ osmium tetroxide in the same buffer for $4 \mathrm{~h}$. Following post fixation, the samples were dehydrated in a graded series of acetone (30 to 100\%), which included en bloc staining in $70 \%$ acetone saturated with uranyl acetate. The samples then were infiltrated and embedded in Spurr resin. Ultrathin sections were prepared using a, RMC MTXL ultramicrotome, placed on copper grids, and stained with lead citrate. Purified virus samples were diluted with PBS to a concentration of $250 \mu \mathrm{g} / \mathrm{ml}$, placed on a formvar-coated copper grid, and stained with $1 \%$ PTA at $\mathrm{pH}$ 7.0. Ultrathin sections and purified virus samples were examined and photographed using a JEOL JEM 100CX transmission electron microscope.

Host range. In total, 116 species in 74 genera in 10 families were inoculated with SuMV. Seed and plants were obtained from the USDA National Seed Storage Laboratory (Ft. Collins, CO), USDA Plant Introduction Stations (Ames, IA; Tifton, GA; and
Pullman, WA), Thompson and Morgan Inc. (Jackson, NJ), local commercial nurseries, and plant breeders at North Dakota State University. For each species tested, four to six plants were grown in individual pots, with the first true leaf inoculated when they were fully expanded (generally 10 to 20 days after emergence), and observed for 4 weeks after inoculation in an insect-free greenhouse. Inoculation procedures were standardized by using symptomatic leaves from sunflower inbred RHA 2713 weeks after inoculation. Noninoculated plants of each species were grown as checks. Back inoculations from plants displaying any type of virus-like symptoms were made onto sunflower inbred RHA-271. Plant species tested, grouped by plant family, included Amaranthaceae: Amaranthus caudatus L. and Gomphrena globosa L.; Asteraceae: Arctium lappa L., Bidens cernua L., B. humilis L., Centaurea repens L., Cichorium endiva L., Cichorium intybus L., Cynara cardunculus L., Lactuca sativa L., L. serriola L., Scorzonera hispanica L., Tragopogon porrifolius L., and Zinnia elegans Jacq.; Brassicaceae: Brassica napus L. and B. rapa L.; Chenopodaceae: Beta vulgaris N., Chenopodium album L., C. amaranticolor Coste \& Rey, C. ambrosoides L., C. capitatum L., C. foliosum L., C. giganteum L., and C. quinoa Wild; Cucurbitaceae: Cucumis sativus L., Cucurbita maxima Duchesne, C. pepo L., and Lagenaria sicerari (Molina) Standl.; Fabaceae: Desmodium tortuosum L., Phaseolus vulgaris L., Pisum sativum L., Vicia faba L., Vigna sinensis (L.) Endl., V. unguiculata L.; Iridaceae: Belamcanda chinensis (L.) DC; Lamiaceae: Pogostemon cablin (Blanco) Benth.; Solanaceae: Capsicum annuum L., C. baccatum var. praetermissum L., C. chinense L., C. fructescens L., Datura metel L., D. meteloides L., D. stramonium L., Lycopersicon esculentum Mill.; Nicandra physaloides L., Nicotiana benthamiana L., $N$. clevelandii L., $N$. debneyi L., $N$. glutinosa L., $N$. rustica L., $N$. sylvestris L., N. tabacum L. (cvs. Havana 425, Samsun, and Xanthi), Petunia $\times$ hybrid Hort. Vilm.-Andr., and Physalis pubescens L.; Tropaeolaceae: Tropaeolum nanum L. and T. majus L.

Multiple cultivars of Capsicum, Lactuca, and Cichorium spp. were tested after preliminary serological tests suggested a possible relatedness with Lettuce mosaic virus (LMV), Tobacco etch virus (TEV), or Endive necrotic mosaic virus (EnNMV). USDA Plant Introduction (PI) numbers and names of cultivars tested included Capsicum annuum: PI 164733, 172776, 176466, 195302, 201231, 209655, 264281, 342946, 343948, and 593571; C. chinense: PI 152225, 159236, 159241, and 294453; Lactuca sativa: Black Seeded Simpson, Buttercrunch, Calmar, Crisp as Ice, Deer Tongue, Green Butterhead, Nancy, Pavane, Prizehead, Salinas, Vanguard 75, Vanity, PI 206965 and 358038; L. serriola: PI 273589, 273617, and 274807; Cichoryium endiva: Bianca Riccia, Full Heart Batavian, and Coral; Cichorium intybus: Catalogna

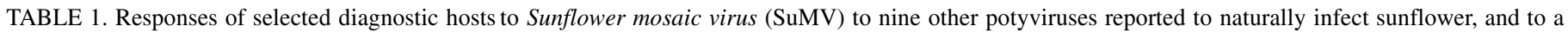
closely related potyvirus, Columbian datura virus $(\mathrm{CDV})^{\mathrm{y}}$

\begin{tabular}{|c|c|c|c|c|c|c|c|c|c|c|c|}
\hline \multirow[b]{2}{*}{ Hosts } & \multicolumn{11}{|c|}{ Virus $^{\mathrm{z}}$} \\
\hline & ArLV & BiMoV & BiMV & $\mathrm{CDV}$ & ClYVV & PatMoV & PVMV & SuCMV & SuMV & TEV & TV-2 \\
\hline Capsicum annuит & NI & NI & NI & NI & NI & NI & MO & nt & NI & MO & nt \\
\hline Chenopodium quinoa & LL & LL & LL & $\mathrm{nt}$ & LL & LL & $\mathrm{LL}$ & LL & LL & LL & nt \\
\hline Chenopodium amaranticolor & LL & LL & LL & nt & LL & LL & LL & LL & NI & LL & nt \\
\hline Datura metel & nt & nt & nt & $\mathrm{W}$ & NI & $\mathrm{nt}$ & MO & $\mathrm{CMO}$ & NI & MO & LL \\
\hline Datura stramonium & $\mathrm{MO}$ & $\mathrm{nt}$ & $\mathrm{NI}$ & LL & $\mathrm{NI}$ & $\mathrm{NI}$ & $\mathrm{MO}$ & $\mathrm{NI}$ & NI & MO & nt \\
\hline Gomphrena globosa & LL & NI & NI & LL & $\mathrm{S}$ & NI & NI & $\mathrm{CMO}$ & NI & $\mathrm{S}$ & nt \\
\hline Lactuca sativa & NI & MO & MO & $\mathrm{nt}$ & $\mathrm{NI}$ & $\mathrm{NI}$ & $\mathrm{S}$ & NI & NI & $\mathrm{nt}$ & $\mathrm{nt}$ \\
\hline Nicotiana spp. & MO & LL & MO & LL & LL & LL & MO & $\mathrm{CMO}$ & NI & MO & LL, Chl \\
\hline Phaseolus vulgaris & $\mathrm{NI}$ & $\mathrm{NI}$ & NI & $\mathrm{nt}$ & MO & $\mathrm{NI}$ & $\mathrm{NI}$ & $\mathrm{NI}$ & NI & $\mathrm{NI}$ & nt \\
\hline Pisum sativum & $\mathrm{NI}$ & $\mathrm{NI}$ & MO & nt & $\mathrm{S}$ & nt & NT & NI & NI & $\mathrm{NI}$ & nt \\
\hline Zinnia elegans & $\mathrm{NI}$ & $\mathrm{MO}$ & $\mathrm{MO}$ & nt & MO & $\mathrm{MO}$ & $\mathrm{MO}$ & $\mathrm{MO}$ & $\mathrm{MO}$ & $\mathrm{S}$ & LL \\
\hline
\end{tabular}

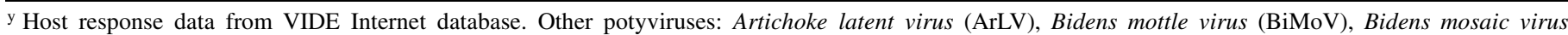
(BiMV), Clover yellow vein virus (ClYVV), Pathchouli mosaic virus (PatMoV), Pepper veinal mottle virus (PVMV), Sunflower chlorotic mottle virus (SuCMV), Tobacco etch virus (TEV), and Tropaeolum virus 2 (TV-2).

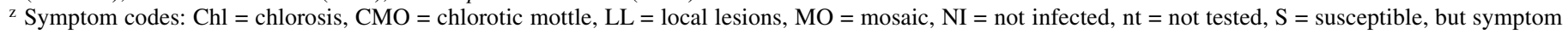
type not specified in literature, $\mathrm{W}=$ wilt and death. 
Special, Flash, and Trevisio Red Preco. Back inoculations were made from all cultivars of Capsicum, Lactuca, and Cichorium tested, regardless of symptoms, to determine if SuMV caused symptomless infections on any of these plants.

In addition to the above plants, an effort was made to examine a representative number of ornamental plants from different genera within the Asteraceae family. Fifty-five species (four to six plants each) within 38 genera were tested, including Achillea ptarmica L., Ageratum houstonianum Mill., A. retroflexus L., Arctium lappa L., Arctotis stoechadifolia Bergius, Aster lateriflorus (L.) Britton, A. nova-angeliae L., Bellis perenis L., Berlandiera lyrata L., Boltonia asteroides (L.) L'Her., Brachycome iberidifolia Benth., Bupthalmum salififolium L., Calendula officinalis L., Catananche caerulea L., Centaurea dealbata L., C. macrocephala MussinPuschk, C. montana L., C. moschata L., C. cyanus L., Chrysanthemum leucanththemum L., C. maximum Ramond, C. $\times$ morifolium Ramat., C. tenuiloba L., Coreopsis grandiflora Hogg ex Sweet, C. lanceolata L., Cosmos bipinnnatus Cav., Dahlia pinnata Cav., Dimorphotheca sinuata DC., Echinacea purpurea (L.) Moench, Echinops ritro L., Erigeron karvinskianus DC., E. speciosus (Lindl.) DC., Gaillardia aristata Pursh, Gazania rigens L., Helenium autumnale L., Helichrysum cassinianum L., Heliopsis helianthoides (L.) Sweet, Liatris spicata (L.) Willd., L. pycnostachya Michx., Matricaria inodora L., Melampodium perfoliatum (Cav.) Kunth., Microseries ringens L., Pyrethrum roseum Bieb., Rudbeckia californica Gray, R. fulgida Ait., R. hirta L., $R$. nitida Nutt., Sanvitalia procumbens Lam., Senecio cineraria DC., Tagetes erecta L., Tithonia rotundifolia (Mill.) S. F. Blake, Xeranthemum anuum L., Zinnia angustifolia Kunth, Z. haageana Regel, and Z. pauciflora L. Additionally, some common North American Asteraceae classified as weeds were tested, including: Ambrosia artemisifolia L., A. trifida L., Cirsium arvense (L.) Scop, Iva xanthifolia Nutt., Sonchus arvensis L., and Xanthium strumarium L.

Sunflower host range. A total of 52 oilseed and confection hybrids from the United States, Europe, and South Africa were tested by mechanical inoculation as described above, with six to eight plants of each hybrid. Commercial hybrids from the United States included cvs. Agway 3631, 3733, 4033, and 4231; Cargill 187 and 270; Cenex 119, 745, and 810; Dekalb 3795 and 3828; Genetic Resources 7392 and 9501; Mycogen 658 and Cavalry; Novartis 231, 259, and X12244; Pioneer 6338, XF-469, and D151; Seed America Bigfoot and Kodiak; Sigco 828 and 954; and Triumph 505C, 520C, 545, 546, and 571. Hybrids from European and South African companies included Agricol 3037, Agrisol, Alamo, Albena, Alex, Andora, Claudia, Eva, Gala, HB 9612, Hysun 321 and 341, Maya, NSH 410 and 605, Pannar 7351 and 7392, Performer, Rustica 931, Sensako 75, Trakya, and the openpollinated cv. Krasnodarets.

Effect on seed yield. Two-week-old plants of three commercial sunflower hybrids (oilseed types Cargill 208 and Triumph 546 and confection type Sigco 954) and three USDA inbred lines (RHA 271, RHA 358, and RHA 858) were sap inoculated as described. When symptoms appeared, 10 to 14 days after inoculation, six infected plants and six noninoculated control plants of each of the six genotypes were individually planted in 11.3-liter plastic pots filled with sandy loam. The plants were maintained in an insectfree greenhouse at $24^{\circ} \mathrm{C}$ with a 16-h photoperiod. At physiological maturity (growth stage R9, when the bracts become yellow and brown), plant height, leaf number, and total seed yield were determined on both virus-infected and control plants. This experiment was conducted twice.

Aphid transmission. Two aphid species were evaluated for their capacity to transmit this virus: Capitphorus elaegni (Del Guerico) and Myzus persicae (Sulzer). C. elaegni, known as the Russian olive aphid, is polyphagous and is a common inhabitant of greenhouses in the United States. The aphid was collected from and maintained on greenhouse-grown sunflower. $M$. persicae, the green peach aphid, is commonly observed on wild and cultivated sunflower throughout the United States. A colony of M. persicae was obtained from the University of Minnesota and maintained on Chinese cabbage (Brassica pekinensis L.). Apterous adult aphids were transferred with the aid of a small brush to petri dishes and starved for $1 \mathrm{~h}$. The aphids then were placed on sunflower line RHA 271 showing mosaic symptoms, and allowed an acquisition access period of $15 \mathrm{~min}$. The aphids then were transferred to 2-week-old, healthy RHA 271 sunflower plants (five aphids/plant), allowed to feed overnight, and killed the next morning with malathion. Inoculated plants were observed over a 3-week period for symptoms. A total of 120 sunflower plants (40 plants in three independent trials) were tested with each aphid species.

Seed transmission. Four hundred seed from greenhousegrown, symptomatic plants of cv. Triumph 546 and an additional 400 seed from greenhouse-grown, symptomatic plants of Sigco 954 sunflower were planted in an insect-free greenhouse in 12-cm-square pots and grown for 6 weeks to observe for virus symptoms. Leaves showing any virus symptoms were harvested from plants individually, and used to sap inoculate four plants of RHA 271 to confirm presence of SuMV.

Virus and viral RNA purification, cDNA synthesis, and sequence analysis. Sunflower mosaic virus was purified using a modification of the procedure outlined in Berger and Shiel (3). Briefly, 100 to $200 \mathrm{~g}$ of sunflower or zinnia tissue was harvested 10 days after inoculation and homogenized in $400 \mathrm{ml}$ of grinding buffer $(0.5 \mathrm{M}$ borate buffer, $\mathrm{pH} 8.0$, containing $0.15 \%$ [ $\mathrm{vol} / \mathrm{vol}]$ thioglycolic acid). Chloroform (100 ml) was added, homogenized briefly, and centrifuged at $10,000 \times g$ for $20 \mathrm{~min}$ at $4^{\circ} \mathrm{C}$. The aqueous phase was filtered through a large laboratory tissue (i.e., Kimwipe) supported by cheesecloth and centrifuged at $68,000 \times g$ for $1.5 \mathrm{~h}$ at $4^{\circ} \mathrm{C}$. The pellet was resuspended in $0.05 \mathrm{M}$ borate buffer $(\mathrm{pH} 8.0)$ containing $5 \mathrm{mM}$ EDTA and centrifuged at $10,000 \times g$ for $10 \mathrm{~min}$ at $4^{\circ} \mathrm{C}$ to remove insoluble matter. The supernatant was collected and subjected to another round of high speed/low speed centrifugation before final purification by 10 to $40 \%$ sucrose density gradient centrifugation prepared in borate buffer. The purified virus was analyzed by UV spectrophotometry using a Beckman DU-50 spectrophotometer. Purified virus was used for antisera production, serological tests, analysis of coat protein (CP) by sodium dodecyl sulfate-polyacrylamide gel electrophoresis (SDSPAGE), and for RNA isolation for cDNA synthesis and cloning.

RNA was extracted from purified virions, cloned as described in Berger and Shiel (3), and compared with RNA standards (Life Technologies, Rockville, MD) by $1.2 \%$ denaturing gel electrophoresis. Plasmids containing sizable inserts were analyzed by restriction enzyme mapping and were further purified for doublestranded DNA sequencing. The DNA was sequenced on both strands by the dideoxy-chain termination method using the Sequitherm Long-Read Cycle Sequencing Kit (Epicentre Technologies, Madison, WI) following the manufacturer's protocols and analyzed using a Licor 4000L automated DNA sequencer and IRD-41 labeled primers (Licor, Inc., Lincoln, NE). Large inserts were subcloned for further sequencing.

Phylogenetic analysis of the capsid protein sequence was essentially as described in Berger et al. (4), except that quartet puzzling was used rather than bootstrap analysis. A subset of sequences described in Berger et al. (4) was chosen that provided a range of potyviruses with particular attention to those taxa most closely related to SuMV, and was used for phylogenetic analyses. Multiple sequence alignments were done using PILEUP, and were examined visually and modified as necessary.

Determination of virion physical properties and capsid protein molecular weight. Purified virus was subjected to analytical ultracentrifugation (Beckman XL-A) at $20^{\circ} \mathrm{C}$, using the manufacturer's instructions to determine the sedimentation coefficient. This was done at the Institute of Biological Chemistry, Washington State University (Pullman, WA). For determination of ap- 
proximate molecular weight by SDS-PAGE, $1 \mu \mathrm{g}$ of purified virus was dissociated (15) by boiling for $5 \mathrm{~min}$, then loaded into each of two lanes of a $12.5 \%$ SDS-PAGE gel. Broad range protein molecular weight standards (BRL) $(3 \mu \mathrm{l})$ was treated the same way and loaded onto two wells adjacent to the purified virus sample. One microgram of purified preparations of Tobacco vein mottling virus (TVMV), Potato virus Y (PVY), TEV, and Bean common mosaic virus (BCMV) strain US-1 were treated as above and examined in the same gel. The gel was run for $2.5 \mathrm{~h}$ at $6 \mathrm{~W}$ constant power, rinsed, and stained with Coomassie Brilliant Blue R-250.

Serological assays and titer of SuMV over time. Antisera was produced by emulsifying $100 \mu \mathrm{l}$ of purified virus $(1 \mathrm{mg} / \mathrm{ml})$ in $100 \mu \mathrm{l}$ of Titermax Gold research adjuvant (CytRx Corp., Norcross, GA) and injected intramuscularly into New Zealand white rabbits at 2-week intervals for seven injections. One week after the third injection, and weekly thereafter, a test bleed was drawn to determine the titer of the antisera.

The titer of SuMV in sunflower versus zinnia appeared to be different on the basis of preliminary observations. Therefore, indirect enzyme-linked immunosorbent assay (ELISA) was used to determine the relative accumulation of SuMV in these hosts. The sunflower confection hybrid Sigco 954, oilseed hybrid Triumph 546, and USDA inbred line RHA 271, as well as zinnia cvs. B's Big Tetra and Giant Flowered (W. Atlee Burpee \& Co., Warminster, PA) were inoculated with purified SuMV at $10 \mu \mathrm{g} / \mathrm{ml}$ in $0.05 \mathrm{M}$ sodium phosphate buffer, $\mathrm{pH} 7.0$, containing $0.02 \mathrm{M}$ sodium sulfite. Two $0.9-\mathrm{cm}$ leaf disks were taken from each plant just prior to inoculation. At 5, 10, 20, 30, and 40 days postinoculation, two $0.9-\mathrm{cm}$ leaf disk samples were taken from the third expanding leaf of each inoculated plant, avoiding the inoculated leaf. Mock-inoculated hosts planted at the same time were sampled in the same manner. The leaf disks for ELISA were ground in $0.05 \mathrm{M}$ carbonate buffer, $\mathrm{pH} 9.6$, with 1\% PVP and $0.1 \%$ egg albumin (Grade II; Sigma Chemical, St. Louis). Prepared samples were stored at $-20^{\circ} \mathrm{C}$ until use in ELISA. Indirect ELISA of all samples was performed at the same time. Sample $(100 \mu \mathrm{l})$ was loaded into each well of a PRO-BIND 96-well flatbottom microtiter plate (Becton Dickinson Labware, Franklin Lakes, NJ). Each sample was placed into duplicate wells. The plate also contained buffer-only controls and a dilution series of purified SuMV ranging from 1 to $1,000 \mathrm{ng} / \mathrm{ml}$ concentration.

Samples were incubated overnight at $4^{\circ} \mathrm{C}$, and the wells were then washed three times for $10 \mathrm{~min}$ each in phosphate-buffered saline (PBS) with 0.5\% Tween 20. Purified anti-SuMV immunoglobulin $\mathrm{G}(100 \mu \mathrm{l})$, cross-absorbed against healthy zinnia tissue and diluted to $1 \mu \mathrm{g} / \mathrm{ml}$ in PBS containing $1 \%$ PVP and $0.1 \%$ egg albumin (PEP buffer), then was added to each well and incubated at $37^{\circ} \mathrm{C}$ for $3 \mathrm{~h}$. The contents were removed, washed as above, and a 1/8,000 dilution of goat anti-rabbit alkaline phosphatase conjugate (Sigma-Aldrich) in PEP was added to each well and incubated for $2 \mathrm{~h}$ at $37^{\circ} \mathrm{C}$. The conjugate was removed, the plates washed as above, and a solution of p-nitrophenyl phosphate conjugate (Sigma-Aldrich) at $1.0 \mathrm{mg} / \mathrm{ml}$ in $9.7 \%$ diethanolamine, $\mathrm{pH}$ 9.8, was added to the wells and allowed to incubate for $3 \mathrm{~h}$ at room temperature. The optical density $(\mathrm{OD})_{405}$ was determined using a microplate reader (Model EL311; Bio-Tek, Winooski, VT).

Monoclonal antibody serological comparisons. SuMV was compared with six other potyviruses by means of 25 monoclonal antibodies (MAbs), designated "PTY" MAbs (13). Members of this panel of MAbs distinguish epitopes that are (i) characteristic of recognized strains and isolates of Bean yellow mosaic virus (BYMV), (ii) common to members of the BYMV subgroup, (iii) distinctive for unique potyviruses, or (iv) common to most distinct potyviruses $(13,14)$. These viruses also were tested against six other MAbs generated against Tulip breaking virus (TBV) (provided by H. T. Hsu), some of which were shown to react to isolates of TBV and some which were shown to react to several distinct potyviruses $(10,12)$ (R. L. Jordan, unpublished data). Sources of purified potyvirus isolates included in comparisons with monoclonal antibodies were as indicated by Jordan and Hammond (13). Virus samples were evaluated using the PTY and TBV MAbs in an indirect antigen-coated plate ELISA (ACPELISA) as described $(11,13)$. Purified viruses were diluted to $2 \mu \mathrm{g} / \mathrm{ml}$ in $0.05 \mathrm{M}$ carbonate buffer and dispensed to duplicate wells of Nunc MaxiSorp (Roskilde, Den) polystyrene ELISA plates.

\section{RESULTS}

Sunflower inoculation parameters. Sunflower plants, inoculated 11 to 17 days after planting, developed mosaic symptoms 8 to 12 days later in the newly emerged leaves at the apex. Whereas all six of the initial sunflower genotypes tested were susceptible, the USDA inbred line RHA 271 was chosen for routine virus maintenance because it could be increased easily by self-pollination and had a public pedigree. Some genotypes, such as USDA line RHA 858, were so susceptible that infected plants often died. Spraying plants with the growth regulator B-Nine had no effect on symptom expression in either sunflower or zinnia. This growth regulator routinely has been used in all of our greenhouse experiments to keep sunflowers to a manageable height by reducing internode length. Averaged over two sunflower and two zinnia cultivars, $81 \%$ of plants receiving a B-Nine spray developed mosaic symptoms compared with $73 \%$ of the unsprayed plants. The growth regulator application was especially useful with sunflower hybrids in order to keep greenhouse-grown plants at a manageable height. The addition of sodium sulfite $(1 \%$, wt/vol) and PVP $(0.25 \%, \mathrm{wt} / \mathrm{vol})$ to the phosphate buffer had a marked effect on infectivity of SuMV. Sunflower leaf disks ground in phosphate buffer plus the antioxidants resulted in symptom development in $71 \%$ of inoculated plants compared with $30 \%$ of inoculated plants when the antioxidants were not added. The effect of sunflower plant age at inoculation had a similar marked effect on symptom expression (Table 2). Plants of RHA 271 inoculated at 11 days after planting, when the first leaves were approximately 2 to $3 \mathrm{~cm}$ long, developed symptoms in $98 \%$ of the plants. The transmission rate of SuMV decreased when older plants were inoculated. No mosaic symptoms developed when 32-day-old plants were inoculated. There was no apparent difference in the time required for symptom expression when different age plants were inoculated.

Microscopy. Examination of leaf dips from naturally infected wild $H$. annuus leaves revealed the presence of long, flexuous rods, confirming the presence of a virus. Measurements of particles from a purified virus preparation revealed particle lengths ranging from 575 to $867 \mathrm{~nm}$. Presumably, short particles observed were the result of breakage occurring during the purification process, but occasional particles $>860 \mathrm{~nm}$ also were observed, and these were presumed to be end-to-end aggregates. On the basis of measurement of 100 particles, the mean particle length was $723 \mathrm{~nm}$, with a median of $710 \mathrm{~nm}$ and a standard deviation of

TABLE 2. Effect of sunflower plant age at inoculation on susceptibility to sunflower mosaic symptom expression

\begin{tabular}{lc}
\hline Plant age at inoculation (days) & Plants with symptoms $(\%)^{\mathrm{z}}$ \\
\hline 11 & $98 \mathrm{a}$ \\
14 & $63 \mathrm{~b}$ \\
17 & $46 \mathrm{bc}$ \\
21 & $35 \mathrm{c}$ \\
24 & $11 \mathrm{~d}$ \\
28 & $10 \mathrm{~d}$ \\
32 & $0 \mathrm{~d}$
\end{tabular}

${ }^{\mathrm{z}}$ Based on symptom expression 14 days after sap inoculation. Values followed by different letters are statistically significantly different based on Duncan's multiple range test $(P=0.05)$. 
$68.4 \mathrm{~nm}$. TEM observations of sunflower leaves showing mosaic symptoms failed to show individual virus particles, but there were numerous examples of both pinwheel inclusion bodies and laminated aggregates in the cytoplasm (Fig. 1).

Host range. Of the 116 species in 74 genera of plants inoculated, only species in the genera Helianthus, Sanvitalia, and Zinnia, all in the family Asteraceae, developed systemic mosaic symptoms. The reaction of SuMV, in comparison with other potyviruses reported to infect sunflower, on selected plants commonly used as diagnostic hosts for potyvirus is shown in Table 1. All 52 sunflower hybrids, representing commercial oilseed and confec-

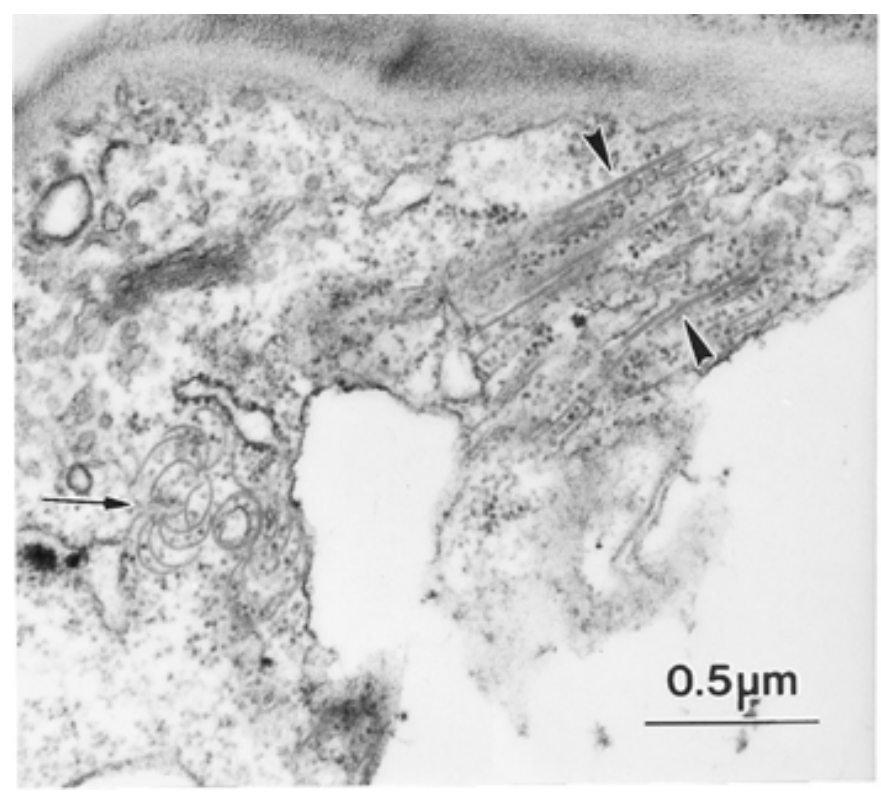

Fig. 1. Electron micrograph of a sunflower leaf mesophyll cell infected with Sunflower mosaic virus, showing cytoplasmic (pinwheel) inclusion bodies and laminated aggregates in the cytoplasm. Bar $=0.5 \mu \mathrm{m}$. tion types marketed in the United States, South Africa, and Europe, were susceptible. Differences in the time of symptom appearance were observed among sunflower hybrids, but all developed systemic mosaic symptoms within 3 weeks after inoculation, with the most susceptible hybrids developing symptoms 1 week after inoculation. Three of the four Zinnia spp. tested ( $Z$. elegans, Z. haageana, and Z. pauciflora) and Sanvitalia procumbens (creeping zinnia) developed mosaic symptoms. Cultivars displaying mosaic symptoms included Cut \& Come Again, Dahlia, Thumbelina, Whirligig, Lilliput, and Paintbrush for Z. elegans; Persian Carpet for Z. haageana; Bonita Red for Z. pauciflora; and Single Yellow for S. procumbens. Z. angustifolia cvs. Star White and Profusion Cherry did not develop mosaic symptoms, and back inoculations were negative. Mosaic symptoms were most pronounced on Z. elegans cvs. Dahlia, Cut \& Come Again, and Whirligig, and on cv. Bonita Red of Z. pauciflora. Mosaic symptoms developed more slowly on Zinnia spp. than on sunflower, with symptoms generally becoming faintly visible 10 to 14 days after inoculation, and severe, depending upon the cultivar, by 3 weeks after inoculation. Virus infection had no effect on flower morphology or color in either Helianthus or Zinnia spp.

None of the other 44 Asteraceae genera tested, representing crop plants, ornamentals, and weeds, developed any type of viruslike symptoms. None of the 14 cultivars of three Capsicum spp., the 15 cultivars of two Lactuca spp., or the six cultivars of the two Cichorium spp. developed any symptoms, and the absence of infection was confirmed by back inoculations. Local lesions were observed on only two species: Chenopodium quinoa, which had chlorotic lesions turning necrotic with age, and C. ambrosoides, which developed red lesions. No systemic symptoms of any type were observed on either $C$. quinoa or $C$. ambrosoides. No local lesions were observed on the other five Chenopodium spp. tested, or on any other solanaceous plants. Local lesions developed in the same time frame as mosaic symptoms, generally appearing 8 to 10 days after inoculation.

Effect of SuMV on sunflower seed yield. Virus infection had a statistically significant effect on seed yield of inbred and hybrid

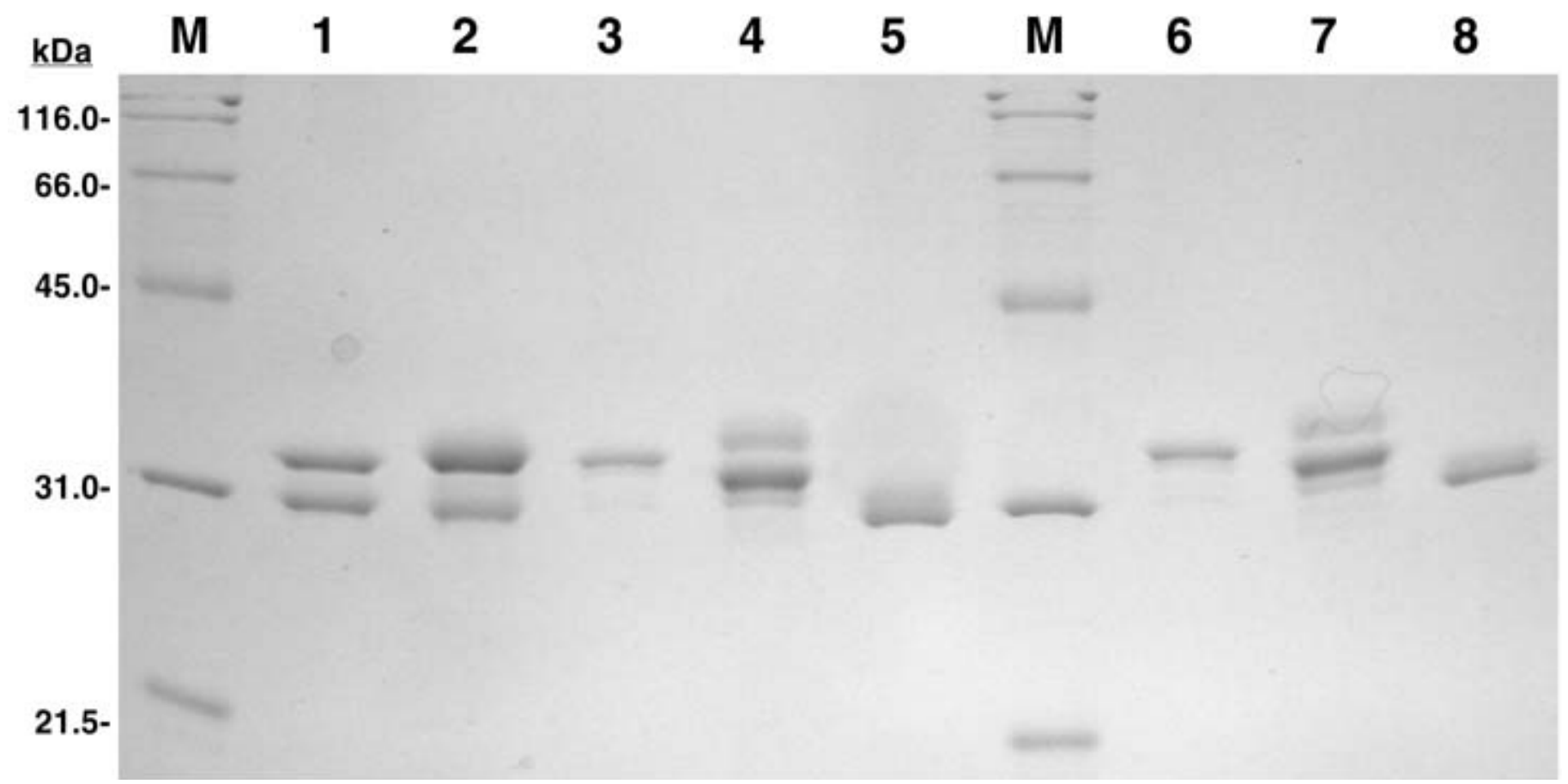

Fig. 2. Analysis of coat proteins of Sunflower mosaic virus (SuMV) and other potyviruses by $12.5 \%$ sodium dodecyl sulfate-polyacrylamide gel electrophoresis. Lane 1, Tobacco vein mottling virus; lane 2, Potato virus $Y$ (strain O); lanes 3 and 6, SuMV; lanes 4 and 7, Tobacco etch virus (strain F); and lanes 5 and 8, Bean common mosaic virus (strain US-1). Lane M, BioRad broad range protein molecular weight standards. 
sunflower, with inbred lines showing the most pronounced yield losses. Of the three inbreds tested, RHA 858 defoliated within 4 to 6 weeks after inoculation, and there was no seed yield because all inoculated plants died. RHA 271 also was quite susceptible, but inoculated plants did flower and reach physiological maturity. RHA 358 developed only mild mosaic symptoms, which took 2 to 3 weeks to appear. Seed yields (grams per plant, averaged over both experiments) of RHA 271 and RHA 358 plants inoculated with SuMV were 51 and 3\% that of control plants, respectively. Of the three hybrids tested, Triumph 546 and Sigco 954 developed symptoms within 10 to 14 days, whereas Cargill 208 took 2 to 3 weeks before clear mosaic symptoms developed. Seed yields of Triumph 546, Sigco 954, and Cargill 208 plants infected with SuMV were 24,58 , and $62 \%$ that of noninoculated plants, respectively. There was no significant difference in plant height or leaf number between virus-infected and healthy plants of either the inbred lines or the hybrids, with $5 \%$ or less difference observed in height or leaf number.

Seed and insect transmission. Both the green peach aphid, $M$. persicae, and the Russian olive aphid, Capitphorus elaegni,

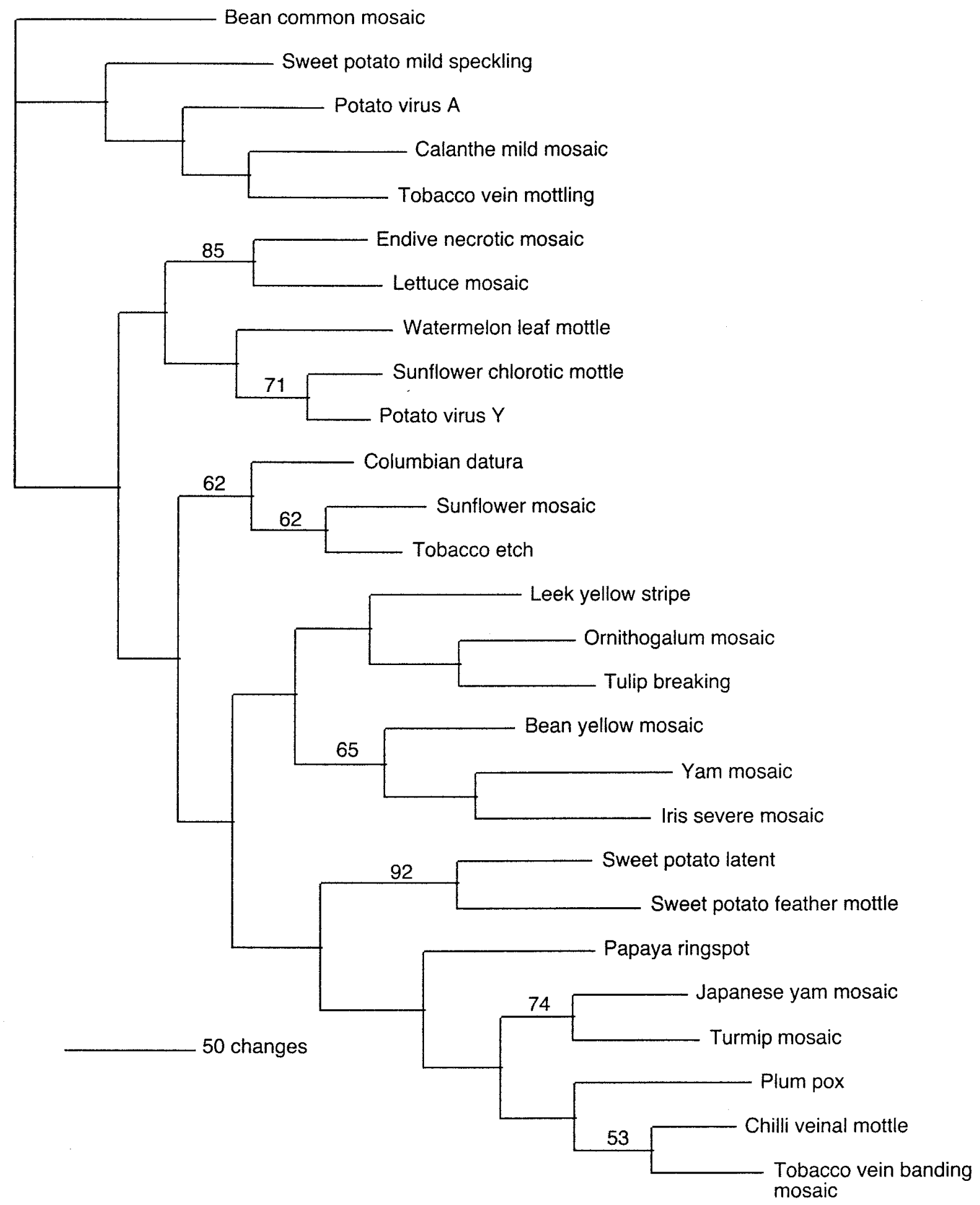

Fig. 3. Phylogenetic analysis with the coat protein amino acid sequences of representative potyviruses. The inference was obtained using maximum parsimony. Branch lengths are proportional to distance, whereas vertical position is arbitrary. The numbers at the bases of some branches are the result of quartet puzzling, and only those values $\geq 50 \%$ are shown. This is an unrooted tree. 
successfully transmitted SuMV from sunflower to sunflower. Symptoms often appeared in 6 to 7 days, several days sooner than observed with sap inoculation. Mosaic symptoms developed in $20 \%$ of sunflower plants exposed to viruliferous Russian olive aphid and $13 \%$ of those exposed to viruliferous green peach aphid. In the seed transmission study, no virus symptoms developed on any of 400 plants grown from seed harvested from Sigco 954 sunflower plants showing mosaic. Back inoculations from 40 randomly selected, symptomless plants onto susceptible line RHA 271 failed to reveal any latent infections. Of the $400 \mathrm{~F} 2$ plants derived from seed of Triumph 546 plants, 47 developed mosaic symptoms $(12 \%)$. These plants displayed either severe mosaic symptoms, which appeared within 2 weeks after emergence, or mild mosaic, which took 2 to 4 weeks to manifest. Back inoculation to sunflower line RHA 271 with sap from plants with mild or severe mosaic resulted in typical mosaic symptoms on all inoculated plants. Back inoculations from 40 symptomless plants failed to result in mosaic symptoms on RHA 271.

Purification of virus and its physical properties, and RNA and sequence analysis. The virus was initially purified from sunflower hybrid Sigco 954, 14 days after inoculation, through the final sucrose density gradient centrifugation step. Yields of virus averaged $2.96 \mathrm{OD}_{260}$ per $100 \mathrm{~g}$ of tissue after sucrose density gradient centrifugation, with a $260 / 280 \mathrm{~nm}$ ratio of 1.30 . However, a light diffusing contaminant was seen in the sucrose density gradient, and this component was more visible in virus preparations from older plants. Yields of virus from infected zinnia were between 2.53 to $3.45 \mathrm{OD}_{260}$ units for every $100 \mathrm{~g}$ of tissue with a 260/280 nm ratio between 1.30 and 1.39 . The visible contaminant found in virus purified from sunflower was not observed in preparations from zinnia. Thus, virus preparations from zinnia were used for the production of antisera and for cDNA synthesis.

SuMV had a sedimentation coefficient of $138 \mathrm{~S}$. This value is slightly lower than for a number of potyviruses for which this information is known (5). We also measured $\mathrm{S}$ values for Pea seedborne mosaic virus and PVY. Our results were in close agreement with values from the literature, with measured $S_{20, W}$ values of 153 and $137 \mathrm{~S}$, respectively, compared with published values of $154 \mathrm{~S}$ and $145 \mathrm{~S}$, respectively.

Approximately 25 to $50 \mu \mathrm{g}$ of RNA was obtained from every milligram of starting purified virions. RNA, when analyzed by
$1.2 \%$ denaturing gel electrophoresis and compared with RNA standards, migrated as a single band at a position corresponding to approximately 9,800 nt. cDNA synthesis from $1 \mu \mathrm{g}$ of oligo d(T)primed RNA, followed by blunt-end ligation into EcoRV digested pBluescript, and transformation into competent DH10 $\beta$ Escherichia coli cells, yielded several hundred white colonies. Approximately $30 \%$ of the white colonies contained inserts of at least $1 \mathrm{~kb}$. Plasmids containing cDNA inserts ranging from 1 to $3 \mathrm{~kb}$ were selected for DNA sequencing.

Assembly of the sequences obtained from seven independent cDNA clones yielded a sequence of 2,646 nt followed by a poly A tail of 8 to at least $20 \mathrm{nt}$. The sequence (GenBank Accession No. AF465545) has a single large open reading frame of 2,472 nt encoding 824 amino acids (aa). This type of genome arrangement is consistent with the $3^{\prime}$ region of the potyvirus genome. Analysis of the sequence using BLAST (1) revealed an amino acid sequence similar to NIa, NIb, and CP sequences of many potyviruses.

Amino acid translation revealed two motifs that were similar to other known potyvirus cleavage sites. One, EYFQ/Q, likely defines the carboxy-end/amino-terminus of the NIa/NIb junction, whereas the other, LYFQ/G, is probably the carboxy-end of NIb and amino terminus of CP. The CP sequence of SuMV is predicted to be 270 aa with a predicted molecular weight of 30,453 Da. Analysis of the CP by SDS-PAGE showed a band migrating between 34.1 to $34.7 \mathrm{kDa}$. which was similar to the migration of the main bands of purified PVY and TVMV (Fig. 2).

A phylogenetic analysis of the predicted CP amino acid sequence of SuMV was conducted with sequences of other members of the genus Potyvirus. Based on previous phylogenetic analyses of Potyviridae CPs (4), a subset of known CP sequences was used, representing a spectrum of viruses. The CP sequence of Ryegrass mosaic virus (RGMV) was included as an outgroup. This analysis indicates that the closest relative of SuMV is TEV, with the next closest relatives being EnNMV and Colombian datura virus (CDV). This relationship was consistent regardless of whether a distance-based method or parsimony was used to generate the phylogenetic inference, and was supported by quartet puzzling analysis. Only the tree generated by parsimony is presented (Fig. 3).

Serology and comparisons using monoclonal antibodies. Polyclonal antisera produced from purified virus was able to de-

TABLE 3. Differentiation of potyviruses by a monoclonal antibody panel in antigen-coated plate enzyme-linked immunosorbent assay (ELISA) ${ }^{\mathrm{x}}$

\begin{tabular}{|c|c|c|c|c|c|c|c|}
\hline \multirow[b]{2}{*}{ Monoclonal antibody } & \multicolumn{7}{|c|}{ ELISA $A_{405}$ values for potyviruses ${ }^{z}$} \\
\hline & SuMV & TEV & TVMV & TBV & OMV & PVY & BYMV \\
\hline PTY 1 & +++ & +++ & +++ & +++ & +++ & +++ & +++ \\
\hline PTY 2 & ++ & +++ & - & +++ & + & + & +++ \\
\hline PTY 3 & - & - & ++ & - & ++ & - & +++ \\
\hline PTY 4 & +++ & - & - & ++ & - & + & +++ \\
\hline PTY 5 & - & ++ & - & - & - & + & ++ \\
\hline PTY 7 & - & ++ & - & - & - & + & ++ \\
\hline PTY 8 & - & ++ & - & - & - & ++ & +++ \\
\hline PTY 9 & - & ++ & - & - & - & + & ++ \\
\hline PTY 10 & +++ & ++ & ++ & + & - & +++ & + \\
\hline PTY 11 & - & + & ++ & - & - & + & ++ \\
\hline PTY 12 & + & + & + & + & + & - & + \\
\hline PTY 13 & - & - & +++ & - & - & - & +++ \\
\hline PTYs 14-43 & - & - & - & - & - & - & +++ \\
\hline TBV 2 & - & - & - & +++ & - & - & - \\
\hline TBV 3 & +++ & - & - & +++ & - & - & ++ \\
\hline TBV 4 & +++ & - & - & +++ & - & - & ++ \\
\hline TBV 5 & - & - & +++ & +++ & +++ & - & - \\
\hline TBV 6 & - & - & - & + & - & - & - \\
\hline TBV 7 & +++ & +++ & - & +++ & +++ & +++ & - \\
\hline
\end{tabular}

$\bar{x}$ Virus at $2 \mu \mathrm{g} / \mathrm{ml}$ diluted in coating buffer and direct coating of Nunc Maxisorp ELISA plate.

y PTY = potyvirus monoclonal antibody panel as described by Jordan and Hammond (16); TBV = monoclonal antibodies as described by Hsu et al. (12).

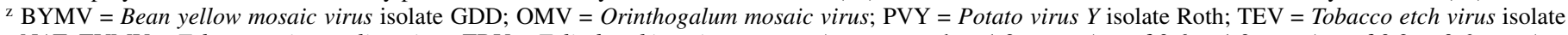
NAT; TVMV $=$ Tobacco vein mottling virus; TBV $=$ Tulip breaking virus. $+++=A_{405}$ greater than $1.2 ;++=A_{405}$ of 0.6 to $1.2 ;+=A_{405}$ of 0.2 to $0.6 ;-=A_{405}$ less than 0.2 . 
tect as little as $10 \mathrm{ng} / \mathrm{ml}$ of purified virus when virus was coated onto microtiter plates and used in an indirect ELISA with the primary antibody at $1 \mu \mathrm{g} / \mathrm{ml}$ concentration. The antisera also could detect TEV-F at $100 \mathrm{ng} / \mathrm{ml}$. The reaction profile of SuMV against the PTY and TBV MAb panel (Table 3) is distinct from any potyvirus previously tested (12-14), with a reaction profile most similar to that of TBV. Reactions of SuMV with these 31 MAbs indicate that the virions share epitopes possessed by many other aphidborne potyviruses, including TBV, TEV, and TVMV (as defined by MAbs PTY 1, 2, 4, and 10 and TBV 3, 4, and 7). However, SuMV does not possess the TBV-specific or BYMV-specific epitopes defined by MAbs TBV 2 and 6 and PTYs 14-43, respectively. Moreover, SuMV does not possess several epitopes, as defined by MAbs PTY 3, 5, 7, 8, and 9 and TBV 5, which are common to many other potyviruses (10-14) (R. L. Jordan, unpublished data).

Virus titer in sunflower and zinnia. The analysis of SuMV titer over time in different hosts was determined by ELISA (Fig. 4). The two zinnia cultivars used in this experiment both accumulated and maintained a higher virus titer than the three sunflower cultivars over 40 days after inoculation. It was difficult to detect virus in infected sunflower, presumably due to low titer or poor accumulation of antigen, with positive readings only at 20 days after inoculation (Fig. 4), while symptoms were observed at 8 to 12 days after inoculation. The two cultivars of zinnia accumulated virus much faster than in the three sunflower cultivars and had an $\mathrm{OD}_{405}$ up to 10 times the $\mathrm{OD}_{405}$ of sunflower by day 20 . The virus titer in zinnia remained high throughout the duration of the experiment, whereas the virus titer in sunflower dropped below reliable detection levels after day 20.

\section{DISCUSSION}

In 1999, approximately 1.09 million ha were planted to sunflower in the United States, with $77 \%$ of the acreage concentrated in North and South Dakota, and only $1 \%$ in Texas, where SuMV appears to be confined. Fungal diseases, specifically those caused by Sclerotinia sclerotiorum, are the most economically devastating to U.S. sunflower production, but a new disease such as sunflower mosaic could be quite serious for several reasons. First, there is no resistance to SuMV in commercial sunflower hybrids or in released USDA germ plasm. Second, the potential for widespread dissemination via aphids or seed transmission could result in an epiphytotic should this virus spread from its current foci in southern Texas. Several factors, however, currently diminish the potential for SuMV to become a major problem in the northern Great Plains production area. First, aphids are not considered an economic pest of northern-grown sunflowers, and are usually observed only late in the growing season after flowering. Aphid presence late in the growing season, coupled with decreased susceptibility of sunflower to SuMV once past the seedling stage, also would decrease the potential impact of SuMV in the northern United States. Last, the northern U.S. sunflower production area is 2,000 to 2,400 km from where SuMV has been found, minimizing the potential spread or long-distance dispersal by viruliferous aphids.

SuMV appears to be limited geographically at the moment to southern Texas. In addition to the sites within Cameron and Hidalgo Counties, the southernmost counties along the Rio Grande River, virus symptoms were observed on both wild and cultivated sunflower in 1999 in Karnes and Bee counties of Texas, inland 80 to $160 \mathrm{~km}$ northwest from Corpus Christi. Indirect ELISA results with SuMV-specific polyclonal antisera confirmed that mosaic symptoms were due to SuMV. Use of this polyclonal antisera should prove useful in identifying SuMV in sunflowers with mosaic symptoms from other localities.

SuMV has a narrow host range, limited to cultivated and wild Helianthus annuus, and two other ornamental members of the family Asteraceae, Zinnia spp. and Sanvitalia spp. (creeping

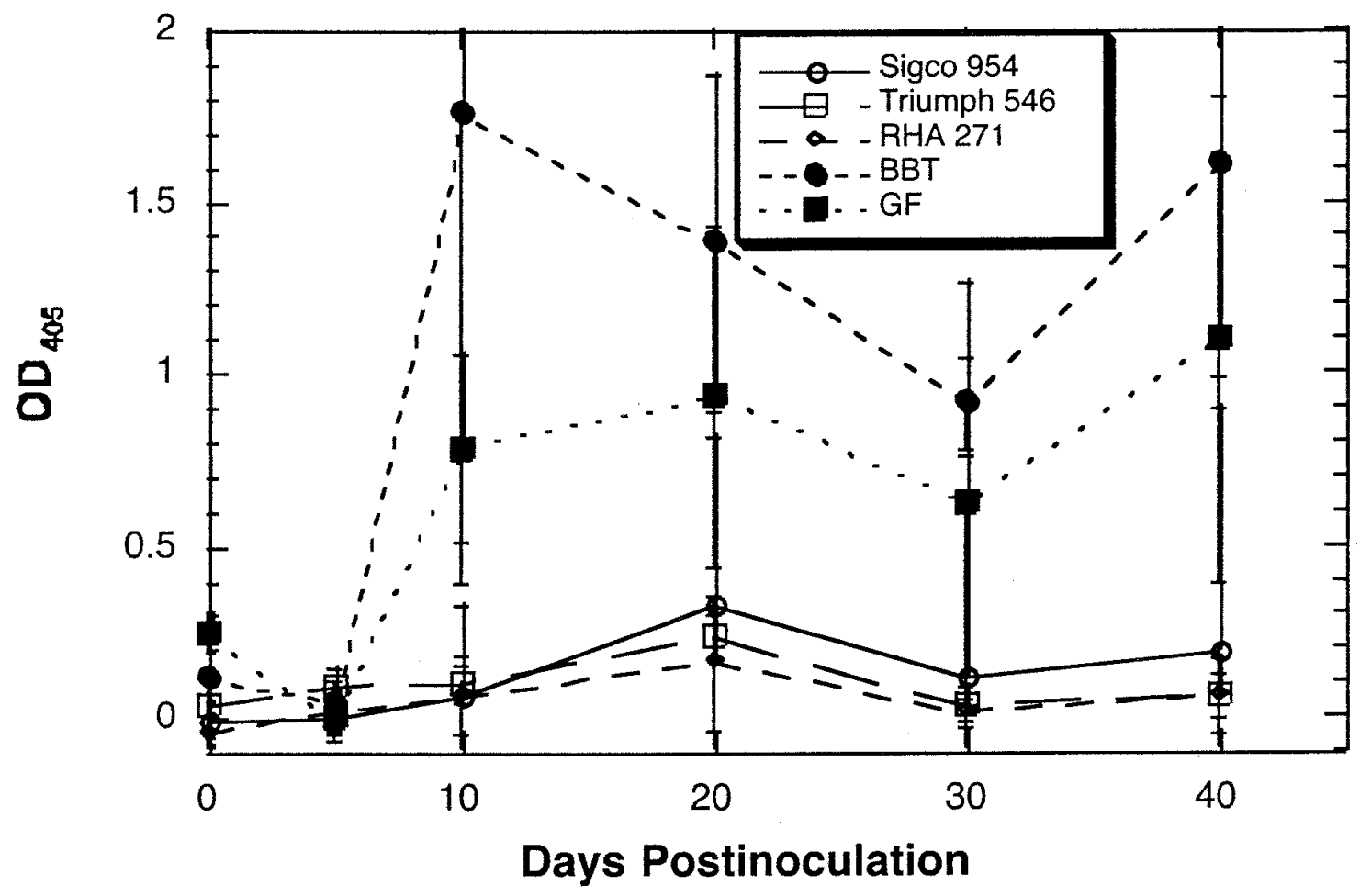

Fig. 4. Time-course of Sunflower mosaic virus (SuMV) accumulation in three sunflower (Sigco 954, Triumph 546, and RHA 271) and two zinnia cultivars (B's Big Tetra $=$ BBT and Giant Flowered $=$ GF) as measured by enzyme-linked immunosorbent assay (ELISA). Data points are the means of four plants for each variety with two ELISA wells for each sample. Optical density $(\mathrm{OD})_{405}$ of virus-infected samples was normalized from the ELISA reading of mock inoculated zinnia or sunflower control plants. Virus inoculated plants were sampled at the time of inoculation and then at 5 and 10 days postinoculation, followed by 10 day intervals up to 40 days postinoculation. 
zinnia). The lack of susceptibility in other ornamentals or crop plants within the family Asteraceae suggests that this virus does not pose a threat to other widely grown ornamentals or to other crop plants. The lack of susceptibility within selected weedy members of the family Asteraceae also minimizes the potential for weeds to serve as alternate hosts for the virus. The marked decrease in susceptibility in sunflower with increasing plant age, at least on the basis of sap transmission, suggests that SuMV has limited opportunities for causing widespread disease in cultivated sunflower, except on young seedlings.

Both of the aphid species tested successfully vectored SuMV, although at different frequencies, with the Russian olive aphid slightly more efficient. Rogers et al. (21) lists 19 aphid species in the genera Aphis, Bipersona, Dactynotus, Macrosiphum, Masonaphis, Myzus, Rhopalosiphum, and Prociphilus as occurring on wild Helianthus spp. or cultivated sunflower in the United States, with Aphis helianthi Monnel and Masonaphis masoni (Knowlton) the most common aphids on sunflower.

SuMV can be seedborne, at least in some cultivars of sunflower, and this could have an impact on SuMV epidemiology. In cv. Sigco 954 sunflower, no seed transmission was observed, but in Triumph 546 a seed transmission rate of $12 \%$ was observed. The titer of virus in Sigco 954 sunflower is low compared with Zinnia cultivars, suggesting that SuMV is better adapted to Zinnia than to sunflower. There was no apparent correlation between virus titer and seed transmission in sunflower, because the virus titer in Triumph 546 was as low as the other two sunflower cultivars tested in which seed transmission did not occur (Fig. 4). The potential for seed transmission in Zinnia spp. which support higher virus titer as determined by ELISA has yet to be determined.

Based on particle morphology and cytopathology, SuMV appears to be typical of viruses in the family Potyviridae. The mean particle length is approximately $723 \mathrm{~nm}$ and the virion sedimentation coefficient is $138 \mathrm{~S}$, both of which are typical for potyviruses, as is the CP molecular weight. Although it is serologically related to TEV, EnNMV, and CDV, SuMV does not have a similar host range as these three viruses. Jordan and Hammond (13) demonstrated that MAbs PTYs 1-13 each define specific epitopes common to members of the potyvirus group, and that the other PTY MAbs each define epitopes either found only on strains of BYMV or shared by BYMV and a few other potyviruses. Other reports have further defined the epitopes detected by these PTY MAbs $(10,11,14)$. MAbs TBV 2 and 6 have been shown to define epitopes present only on TBV, whereas the other TBV MAbs were shown to define epitopes shared by several potyviruses $(10,12,14)$. The reaction profile of SuMV with these MAbs, coupled with the polyclonal antibody studies, indicates that SuMV is a distinct potyvirus possessing a unique serological relationship with TBV and TEV.

Based on CP phylogenetics, SuMV is a unique and distinct potyvirus. Members of the family Potyviridae most closely related to SuMV are TEV, followed by EnNMV and CDV. TEV has $74.4 \%$ amino acid sequence identity with SuMV, indicating that these are distinct viruses and not strains of the same virus (23). The phylogenetic relationship of SuMV, TEV, and CDV is well supported based on quartet puzzling analysis. A potyvirus causing chlorotic mottle on sunflower in Argentina (8) is distinct from SuMV, based on comparison of host range. Furthermore, based on nucleotide sequence (Fig. 3), this virus is a strain of PVY and clearly distinct from SuMV (8).

In summary, SuMV is clearly a distinct member of the family Potyviridae, genus Potyvirus. It has a relatively restricted host range. SuMV has clear serological and phylogenetic relationships with other members of the genus. Based on these data, we propose that SuMV be considered as a confirmed species in the genus Potyvirus.

\section{ACKNOWLEDGMENTS}

We thank S. Halls, who performed the analytical ultracentrifugation at the Institute of Biological Chemistry, Washington State University.

\section{LITERATURE CITED}

1. Altschul, S. F., Madden, T. L., Schäffer, A. A., Zhang, J. H., Zhang, Z., Miller, W., and Lipman, D. J. 1997. Gapped BLAST and PSI-BLAST: A new generation of protein database search programs. Nucleic Acids Res. 25:3389-3402.

2. Arnott, H. J., and Smith, K. M. 1967. Electron microscopy of virusinfected sunflower leaves. J. Ultrastruct. Res. 19:173-195.

3. Berger, P. H., and Shiel, P. J. 1998. Potyvirus isolation and RNA extraction. Pages 151-160 in: Plant Virology Protocols. G. D. Foster and S. C. Taylor, eds. Humana Press Inc., Totowa, NJ.

4. Berger, P. H., Wyatt, S. D., Shiel, P. J., Silbernagel, M. J., Druffel, K., and Mink, G. I. 1997. Phylogenetic analysis of the Potyviridae with emphasis on legume-infecting potyviruses. Arch. Virol. 142:1979-1999.

5. Brunt, A. A., Crabtree, K., Dallwitz, M. J., Gibbs, A. J., Watson, L., and Zurcher, E. J. 1996. Viruses of Plants. Descriptions and Lists from the VIDE Database. Published by CAB International, Wallingford, UK.

6. Chod, J., Skaloud, V., and Jokes, M. 1996. Detection of potato Y virus in the connection with sunflower mosaic symptoms. (In Czech) Sb. UVITZ Ochrana Rostlin 26:11-16.

7. Dijkstra, J. 1983. Tobacco streak virus in sunflower (Helianthus annuus). Neth. J. Plant Pathol. 89:153-169.

8. Dujovny, G., Usugi, T., Shohara, K., and Lenardon, S. 1998. Characterization of a potyvirus infecting sunflower in Argentina. Plant Dis. 82:470474.

9. Gulya, T. J., Berger, P. H., Shiel, P., J., Freeman, T. F., and Isakeit, T. A. 1998. Mosaic-causing potyvirus on wild sunflower from southern Texas. (Abstr.) Phytopathology 88(suppl.):S34.

10. Hammond, J., Jordan, R. L., Larsen, R. C., and Moyer, J. W. 1992. Serological relationships among three filamentous viruses of sweet potato examined using polyclonal and monoclonal antibodies. Phytopathology 82:713-717.

11. Hampton, R. O., Shukla, D. D., and Jordan, R. L. 1992. Comparative potyvirus host range, serology, and coat protein peptide profiles of white lupin mosaic virus. Phytopathology 82:566-571.

12. Hsu, H.-T., Franssen, J. M., van der Hulst, C. T. C., Derks, A. F. L. M., and Lawson, R. H. 1988. Factors affecting epitope specificity of monoclonal antibodies to tulip breaking virus. Phytopathology 78:1337-1340.

13. Jordan, R., and Hammond, J. 1991. Comparison and differentiation of potyvirus isolates and identification of strain-, virus-, subgroup-specific and potyvirus group-common epitopes using monoclonal antibodies. J. Gen. Virol. 72:25-36.

14. Jordan, R. L. 1992. Potyviruses, monoclonal antibodies, and antigenic sites. Arch. Virol. Suppl. 5:81-95.

15. Laemmli, U. K. 1970. Cleavage of structural proteins during the assembly of the head of bacteriophage T4. Nature 227:680-685.

16. McLean, D. M. 1962. Common weed hosts of tobacco ringspot virus in the lower Rio Grande Valley of Texas. Plant Dis. Rep. 48:5-7.

17. Millonig, G. 1961. Advantages of a phosphate buffer for $\mathrm{OsO}_{4}$ solutions in fixation. J. Appl. Phys. 32:1637.

18. Nagaraju, V., Muniyappa, V., Singh, S. J., and Virupahshappa, K. 1997. Occurrence of a mosaic virus disease on sunflower in Karnataka. Indian Phytopathol. 50:277-281.

19. Nishimura, N. T., Kikuchi, S., Tsuda, A., and Tsuchizaki, T. 1995. Cucumber mosaic virus isolated from sunflower (Helianthus annuus L.). Proc. Kanto Tosan Plant Prot. Soc. 42:151-152.

20. Orellana, R. G., and Quacquarelli, A. A. 1968. Sunflower mosaic caused by a strain of cucumber mosaic virus. Phytopathology 58:1439-1440.

21. Rogers, C. E., and Thompson, T. E. 1978. Resistance of wild Helianthus species to an aphid, Masonaphis masoni. J. Econ. Entomol. 71:221-222.

22. Sandbakken, J., and Lilleboe, D. 1999. U.S. Sunflower Crop Quality Report. National Sunflower Association, Bismark, ND.

23. Shukla, D. D., Ward, C. W., and Brunt, A. A. 1994. The Potyviridae. CAB International, Wallingford, UK.

24. Theuri, J. M., Bock, K. R., and Woods, R. D. 1987. Distribution, host range and some properties of a virus disease of sunflower in Kenya. Trop. Pest Manag. 33:202-207.

25. Venugopal, R. R., Madhusudan, T., and Sastry, K. S. 1987. Studies on a mosaic disease of sunflower. J. Oilseeds Res. 4:286-288.

26. Zakusilo, A., Knyaseva, N., Didenko, L., and Boyko, A. 1994. Identification of an Ukrainian virus isolate from Helianthus annuus L. with yellow spot mosaic symptoms. Arch. Phytopathol. Pflanzenschutz 29:13-19. 